\title{
ANALISIS FAKTOR-FAKTOR YANG MEMPENGARUHI PERTUMBUHAN EKONOMI DI PROPINSI BANTEN
}

\author{
Rosalendro Eddy Nugroho \\ Program Studi Pascasarjana Magister Manajemen, Universitas Mercu Buana, Jakarta \\ e-mail: eddynugroho39@yahoo.com
}

Received: August 11, 2016; Accepted: January 26, 2017

\begin{abstract}
ABSTRAK
Besarnya pertumbuhan ekonomi dapat dikatakan sangat penting dalam mengukur keberhasilan pembangunan ekonomi. Hal ini dikarenakan pertumbuhan merupakan salah satu indikator untuk menunjukkan tingkat kesejahteraan akibat daripembangunan ekonomi. Pertumbuhan Ekonomi yang semakin meningkat diikuti puladengan jumlah pengangguran yang meningkat akan meningkatkan investasi perusahaan baik pemodalan dalam negeri dan asing apabila tidak diimbangi dengan peningkatan kesempatan kerja dan upah minimum propinsi. Di Propinsi Banten pertumbuhan ekonomitergolong tinggi selamaperiode waktu 1999 hingga tahun 2013 dengan rata-rata pertahun sebesar 5,392 persen. Pertumbuhan Ekonomi Lokal yang tinggi ini merupakan suatufenomena ekonomi yang terjadi di Propinsi Banten .Tujuan dari penelitian ini adalah untuk menganalisis pengaruh faktor-faktor yang mempengaruhi tingkatpertumbuhan ekonomi di Propinsi Banten.Berdasarkan perhitungan analisis regresi berganda didapatkan hasil bahwa variabel upah berhubungan positif dan signifikan sebesar 2,426, jumlah penganguran berhubungan positif dan signifikan terhadap perumbuhan ekonomi sebesar 2,749 , sedangkan perusahaan modal asing berpengaruh negatif dan signifikan sebesar 0,457, perusahaan modal dalam negeri berhubungan positif dan signifikan sebesar 0,6038. Sedangkan variable kesempatan bekerja berpengaruh negatif dan tidak signifikan terhadaptingkat pengangguran.
\end{abstract}

Kata Kunci: Jumlah Pengangguran, Upah Minimum, Pertumbuhan Ekonomi, PMDN, PMA

\begin{abstract}
The amount national economic growth is important to measuring the success of local economic growth. This is because local economic growth is one of indicator to indicate the level of welfare resulting from economic development. Increasing local economic growth also followed by an increasing number unemployed, wage minimum province and national investment company not offset by decreased employment opportunities and foreign investment company. The number of local economic growth in Banten Province was high for the time period 1999-2013. With average of local economic rate is 5.392 percent each year. The high of local economic growth is economic phenomena in Banten Province. Purpose for this paper is to analysis correlation of factors that influence local economic growth rate in Banten Province. Based on the calculation of multiple regression analysis showed that variables related to national investment company a positive and significant at 0.658, at 2,426 wage minimum province is positively related and significant impact on the unemployment rate amounted to 2.749, foreign investment company has a negative and significant at -0.457 .
\end{abstract}

Keywords: Unemployment, Employment Opportunitie, Local Economic Growth, National Invesment Company, Foreign Invesment Company.

\section{PENDAHULUAN}

\subsection{Latar Belakang Masalah}

Banten adalah salah satu propinsi yang terbentuk awal tahun 2000-an yang merupakan produk Orde Reformasi, sehingga propinsi termuda dalam kerangka
Negara Kesatuan Republik Indonesia (NKRI). Apabila tingkat kemakmuran atau tingkat kesejahteraan rendah wajar saja karena merupakan propinsi termuda, yang berasal dari pemecahan propinsi Jawa Barat. 
Besarnya angka pengangguran dapat dikatakan sangat penting dalam mengukur keberhasilan pembangunan ekonomi. Hal ini dikarenakan pengangguran merupakan salah satu indikator untuk menunjukkan tingkat kesejahteraan akibat dari pembangunan ekonomi. Jumlah penduduk yang semakin meningkat diikuti pula dengan jumlah angkatan kerja yang meningkat akan meningkatkan jumlah pengangguran apabila tidak diimbangi dengan peningkatan kesempatan kerja (Dewi, 2010). Pertumbuhan penduduk yang tinggi, menimbulkan kesulitan kepada Propinsi yang lepas dari propinsi induknya untuk mempertinggi tingkat kesejahteraan masyarakat. Perkembangan penduduk yang semakin cepat dan dalam jumlah yang besar sekalidapat menimbulkan beberapa masalah baru dan salah satu masalah tersebut adalah masalah pengangguran. Sedangkan pertambahan penduduk yang semakin pesat dansemakin besar jumlahnya menyebabkan masalah pengangguran menjadi bertambah buruk Pertumbuhan yang terjadi pada jumlah penduduk dan jumlah angkatan kerja ternyata tidak diimbangi oleh tingginya penyerapan tenaga kerja yang ada. Akibat dari kurangnya penyerapan tenaga kerja yang tersedia akan menimbulkan tingkat pengangguran yang cukup tinggi. (Sukirno, 2005).

Menurut Ekasari (2006) kegiatan investasi memungkinkan suatumasyarakat terus menerus meningkatkan kegiatan ekonomi dan kesempatan kerja, meningkatkan pendapatan nasional dan meningkatkan taraf kemakmuran masyarakat. Peranan ini bersumber dari tiga fungsi penting dari kegiatan investasi, yakni:

1. Investasi merupakan salah satu komponen dari pengeluaran agregat, sehingga Investasi akan meningkatkan permintaan agregat, nasional serta kesempatan kerja.

2. Pertambahan barang modal sebagai akibat investasi akan menambah kapasitas produksi.

3. Investasi selalu diikuti oleh perkembangan teknologi.
Propinsi Banten merupakan satu sentra investasi di Indonesia baik itu untuk industri manufaktur dengan teknologi rendah seperti pabrik sepatu, elektonik, garment dan komponen kendaraan, maupun industri kimia dan petrokimia serta sentra industri besi baja dan industri gula rafinasi. Industri tersebut merupakan industri yang menggunakan industri berteknologi tinggi. Tujuan Penelitian; (a). Menganalisis pengaruh Realisasi PMA \& PMDN, Angkatan Kerja, Upah Minimum dan Jumlah Pengangguran. (b). Menganalisis Faktor yang paling berpengaruh pengaruh Realisasi PMA \& PMDN, Angkatan Kerja, Upah Minimum dan Jumlah Pengangguran.

\subsection{Tinjauan Pustaka}

Pertumbuhan ekonomi merupakan salah satu tujuan penting dari kebijakan ekonomi makro yang akan mampu memberi kesejahteraan masyarakat (Nugrahani dan Tarioko, 2011). Propinsi Banten yang merupakan salah satu satu Provinsi termuda yang dapat digolongkan sebagai Provinsi Baru hasil pemekaran dari Provinsi Jawa Barat. Sebagai Provinsi baru dimana perekonomian bertumpu pada Industri Manufaktur \& Industri Kimia, tetapi memiliki jumlah tenaga kerja yang besar dengan tingkat pengangguran cukup tinggi bila dibandingkan dengan propinsi lain di Indonesia (Merizal, 2008).

Pengangguran merupakan isu penting dalam pembangunan ekonomi di Propinsi Banten dan beberapa indikator ekonomi yang dapat mempengaruhi besarnya tingkat pengangguran diantaranya adalah tingkat inflasi yang terjadi, besaran tingkatupah yang berlaku, tingkat pertumbuhan penduduk dan tingkat kesempatan kerja. Dengan semakin tingginya tingkat inflasi dan tingkat pertumbuhan penduduk makakan berpengaruh pada tingkat pengangguran yang semakin tinggi. Sedangkan semakin tinggi tingkat upah dan tingkat kesempatan kerja akan berpengaruh padatingkat pengangguran yang rendah (Rizka, 2007). 
Pertumbuhan ekonomi merupakan salah satu indikator yang amat penting dalam menilai kinerja suatu perekonomian, terutama untuk melakukan analisis tentang hasil pembangunan ekonomi yang telah dilaksanakan suatu negara atau suatu daerah. Ekonomi dikatakan mengalami pertumbuhan apabila produksi barang dan jasa meningkat dari tahun sebelumnya. Dengan demikian, pertumbuhan ekonomi menunjukkan sejauh mana aktivitas perekonomian dapat menghasilkan tambahan pendapatan atau kesejahteraan masyarakat pada periode tertentu. Pertumbuhan ekonomi suatu negara atau suatu wilayah yang terus menunjukkan peningkatan, menggambarkan bahwa perekonomian negara atau wilayah tersebut berkembang dengan baik (Mustika, 2010).

Berdasarkan pada Hukum Okun (Okun's Law), yang melihat hubungan antara tingkat pengangguran dan Gross Domestic Product (GDP), menyatakan bahwa setiap terjadi peningkatan pada presentase tingkat pengangguran di suatu Negara maka hal tersebut setara dengan terjadinya penurunan terhadap GDP sebesar 2 persen (Griffith dan Wall, 2005). Hal ini mengindikasikan bahwa peningkatan terhadap tingkat pengangguran suatu Negara dapat dikaitkan dengan rendahnya pertumbuhan dalam GDP Negara tersebut (Mankiw, 2006).

Upah merupakan salah satu faktor yang mempengaruhi tingkat pengangguran. Upah merupakan kompensasi yang diterima oleh satu unit tenaga kerja yang berupa jumlah uang yang dibayarkan kepadanya (Mankiw, 2006). Penetapan tingkat upah yang dilakukan pemerintah pada suatu wilayah akan memberikan pengaruh terhadap besarnya tingkat pengangguran yang ada. Semakin tinggi besarnya upah yang ditetapkan oleh pemerintah maka hal tersebut akan berakibat pada penurunan jumlah orang yang bekerja pada Negara tersebut. Oleh karena itu semakin tinggi upah yang ditetapkan akan membawa pengaruh pada tingginya tingkat pengangguran yang terjadi. Hal ini bisa terjadi karena dengan semakin tinggi upah yang ditetapkan maka akan berpengaruh pada peningkatan biaya output yang harus dikeluarkan oleh suatu perusahaan. Akibatnya suatu perusahaan akan melakukan efisiensi terhadap produksi dengan cara mengurangi jumlah tenaga kerjanya.

Beberapa tahun terakhir ini di Indonesia dilanda krisis berkepanjangan. Hal ini berdampak sistem perekonomian semakin terpuruk, hal tersebut mengakibatkan angka pengangguran semakin meningkat. Untuk mengatasi hal tersebut, sebagian masyarakat berinisiatif untuk membuat lapangan pekerjaan sendiri. Akan tetapi untuk melaksanakan hal tersebut membutuhkan modal yang tidak sedikit, jadi tetap ada banyak orang yang menganggur. Oleh karena itu, sebagian besar masyarakat memilih pekerjaan yang tidak sesuai dengan bidangnya (ilmu yang diperoleh), dengan anggapan bahwa lebih baik bekerja daripada tidak bekerja (Soebagiyo, 2005).

Pertumbuhan Ekonomi merupakan salah satu akibat dari adanya fenomena ekonomi yang terjadi. Besarnya tingkat pertumbuhan ekonomi dipengaruhi oleh berbagai halantara lain adalah Investasi dalam negeri, investasi modal asing. tingkat pertumbuhan PDRB, besarnya tingkat upahyang berlaku. Oleh karena itu, diperlukan analisis mengenai pertumbuhan ekonomidan faktorfaktor yang mempengaruhinya di Propinsi Banten.

\subsection{Kerangka Penelitian}

Penelitian ini mengambil faktor relalisasi PMA \& PMDN beserta Angkatan Kerja, Upah Minimum dan Jumlah Pengangguran berpengaruh terhadap Pertumbuhan Ekonomi karena Pertumbuhan Ekonomi suatu daerah atau Propinsi ditentukan banyak atau sedikitnya Investasi dibidang Industri Manufaktur Untuk memudahkan kegiatan penelitian yang dilakukan serta untuk memperjelas akar pemikiran dalam penelitian ini, berikut ini digambarkan suatu kerangka pemikiran yang skematis sebagai berikut. 


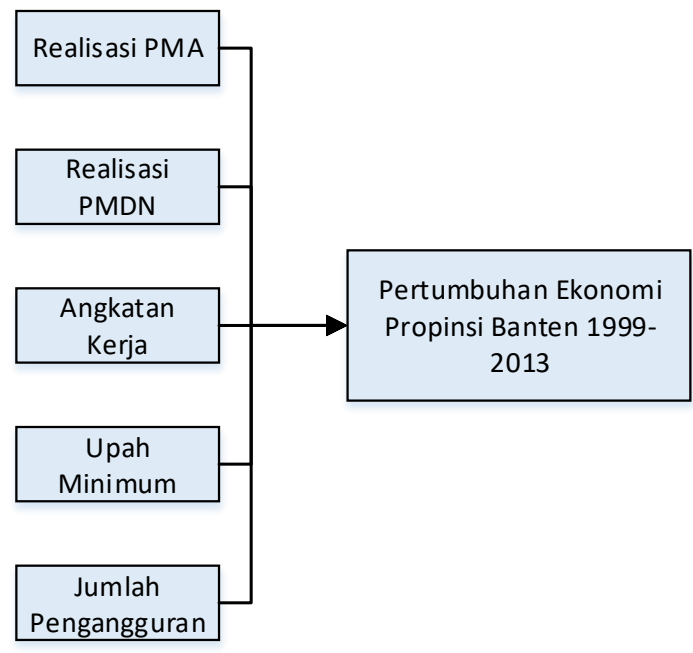

Gambar 1. Kerangka Pemikiran Teoritis

\subsection{Kerangka Pemikiran Teoritis}

Pemikiran pada Gambar 1 dapat dijelaskan bahwa Upah Minimum, Realisasi PMA, Realisasi PMDN, Angkatan kerja, danjumlah pengangguran akan mempengaruhi besarnya tingkat pertumbuhan ekonomi. Perubahan yang terjadi baik padajumlah pengangguran, tingkat upah, Realisasi PMA, Realisasi PMDN akan mengakibatkan perubahan yang terjadi pada tingkat Pertumbuhan Ekonomi di Propinsi Banten.

Dari kerangka pemikiran teoritis tersebut maka posisi penelitian ini terhadap penelitian terdahulu adalah sebagai penelitian yang baru dengan menggabungkan berbagai variabel yang mempengaruhi pengangguran yang bertujuan untuk menunjukkan bahwa semua variabel tersebut merupakan faktor-faktor yang mempengaruhi tingkat pengangguran.

\section{METODOLOGI}

Metode penelitian adalah suatu cara kerja atau prosedur mengenai bagaimana kegiatan penelitian yang akan dilakukan dalam mengumpulkan dan memahami objekyang menjadi sasaran penelitian yang dilakukan.

\subsection{Variabel Penelitian dan Definisi Operasional}

Variabel penelitian adalah segala sesuatu yang akan menjadi objek penelitian, sedangkan definisi operasional adalah suatu definisi yang diberikan kepada suatu variabel dengan memberikan arti (Juanda, 2010). Jadi variabel penelitian inimeliputi faktor-faktor yang berperan dalam peristiwa atau gejala yang akan diteliti. Dalam penelitian ini digunakan dua jenis variabel penelitian, yaitu variableterikat (dependent variabel) dan variabel bebas (independent variabel).

\subsection{Variabel Terikat (Dependent Variabel)}

Tingkat pertumbuhan PDRB merupakan tingkat pertumbuhan ekonomi suatu wilayah/region tertentu. PDRB (Produk Domestik Regional Bruto) merupakan nilai tambah yang dihasilkan oleh semua unit usaha dalam suatu wilayah, atau merupakan semua nilai barang dan jasa akhir yang dihasilkan oleh seluruh unit ekonomi dari suatu wilayah dalam jangka waktu satu tahun. Dalam penelitian ini digunakan laju pertumbuhan PDRB Propinsi Banten menggunakan perhitungan yang digunakan oleh BPS Propinsi Banten. Satuan PDRB pada penelitian ini adalah (\%).

\subsection{Variabel Independen (Independent Variabel)}

Tingkat Upah

Variabel tingkat upah merupakan salah satu faktor yang mempengaruhi tingkat pengangguran karena tingkat upah yang diterima oleh pencari kerja akan mempengaruhi seseorang untuk menganggur dalam waktu tertentu dengan asumsi untuk mendapatkan tingkat upah yang lebih tinggi. Penentuan tingkat upah yang dilakukan dalam penelitian ini adalah menggunakan Perubahan tingkat upah minimum Propinsi Banten dengan satuan $(\%)$.

\section{Realisasi PMDN}

Realisasi PMDN adalah Perubahan jumlah proyek yang telah disetujui serta total investasi yang dikeluarkan dalam satu tahun, yang mana proyek tersebut memperoleh pembiayaan dari sektor swasta yang berasal dari dalam negeri (pembiayaan dari dalam), yang ada di 5 Kabupaten/Kota propinsi Banten dengan satuan (\%). 


\section{Realisasi PMA}

Realisasi PMA adalah Perubahan jumlah proyek yang telah disetujui serta total investasi yang dikeluarkan dalam satu tahun, yang mana proyek tersebut memperoleh pembiayaan dari sektor swasta yang berasal dari Luar Negeri (pembiayaan dari luar). yang ada di 5 Kabupaten/Kota propinsi Banten dengan satuan (\%).

\section{Jumlah atau Angka Pengangguran}

Variabel Jumlah atau Angka Pengangguran adalah penduduk usia produktif terdiri dari penduduk dengan usia15-64 tahun, merupakan data kumulatif per-tahun jumlah orang yang mengangur di propinsi Banten yang diambil dari 5 Kabupaten/Kota. Angka pengangguran merupakan jumlah penduduk yang menganggur, yaitu penduduk yang tidak bekerja sama sekali atau bekerja kurang dari dua hari selama seminggu sebelum pencacahan dan berusaha memperoleh pekerjaan. Variabel tingkat pengangguran yang digunakan adalah pengangguran terbuka (open unemployment) di Propinsi Banten dengan satuan (\%).

\section{Jumlah Angkatan Kerja}

Variabel Jumlah Angkatan Kerja dalam penelitian ini merupakan data kumulatif pertahun jumlah orang yang bekerja di propinsi Banten yang diambil dari 5 Kabupaten/Kota.

\subsection{Jenis dan Sumber Data}

Data dapat diklasifikasikan menjadidata kuantitatif. Jenis data yang digunakan dalam penelitian ini adalah data kuantitatif, yaitu data yangdiukur dalam suatu skala numerik (angka). Data kuantitatif ini berupa data runtutwaktu (time series) yaitu data yang disusun menurut waktu pada suatu variable tertentu (Wahyu, 2009). Dalam penelitian ini menggunakan sumber data sekunder yang dikumpulkan melalui studi literatur baik buku, jurnal penelitian, serta sumber data terbitan beberapa instansi tetentu.

Data yang diperlukan dalam penelitian ini antara lain adalah:

1. Data mengenai besarnya tingkat pengangguran terbuka yang terjadi di Propinsi Banten.
2. Data mengenai Realisasi PMDNPropinsi Banten.

3. Data mengenai besarnya tingkat upah minimum Propinsi Banten.

4. Data mengenai besarnya tingkat PDRB (Produk Domestik Bruto) di Propinsi Banten.

5. Data mengenai Realisasi PMAPropinsi Banten.

6. Data mengenai jumlah atau angkakesempatan bekerja di Propinsi Banten.

\subsection{Metode Pengumpulan Data}

Metode yang dipakai dalam pengumpulan data adalah melalui studi pustaka. Studi pustaka merupakan teknik untuk mendapatkan informasi melalui catatan, literatur, dokumentasi dan lain-lain yang masih relevan dalam penelitian ini. Datayang digunakan dalam penelitian ini adalah data sekunder yang diperoleh dalambentuk sudah jadi dari Badan Pusat Statistik (BPS) Provinsi Bantenserta Badan Pusat Statistik (BPS); kota Serang, kota Cilegon, kota Tangerang, kota Tangerang Selatan, Kabupatan Lebak, Kabupaten Serang, Kabupaten Tangerang dan Kabupaten Pandegelang. Data yang diperoleh adalah data dalam bentuk tahunan untuk masing-masing variabel.

\subsection{Metode Analisis}

Metode analisis dalam penelitian ini menggunakan metode analisis regresi berganda dan uji penyimpangan terhadap asumsi klasik yang meliputi uji multikolinearitas, uji autokolerasi, dan uji heterokedastisitas.

\subsection{Analisis Regresi Berganda}

Dalam menganalisis faktor-faktor yang mempengaruhi tingkat pengangguran di Propinsi Banten, digunakan model:

$Y=\beta_{0}+\beta_{1} L \_P M A+\beta_{2} L \_P M D N+\beta_{3} L \_A K$

$+\beta_{4} L \_J P+\beta_{5} L \_U M R+e$

dimana:

$Y=$ Pertumbuhan ekonomi

$L_{-} P M A=$ Logaritma Realisasi nilai Penanaman Modal Asing (PMA) 
L_PMDN = Logaritma Realisasi nilai Penanaman Modal Dalam Negeri PMDN) $L \_A K=$ Logaritma jumlah angkatan kerja $L \_J P=$ Logaritma Jumlah Pengangguran $L_{-} U M R \quad=\quad$ Upah Minimum Regional/Propinsi.

$e=$ error term

$\beta_{0}=$ intersep

$\beta_{1}=$ koefisien investasi asing (PMA)

$\beta_{2}=$ koefisien investasi dalam negeri (PMDN)

$\beta_{3}=$ koefisien angkatan kerja $(\mathrm{AK})$

$\beta_{4}=$ koefisien jumlah pengangguran (JP)

$\beta_{5}=$ koefisien upah minimum regional atau propinsi (UMR)

\section{HASIL DAN PEMBAHASAN}

\subsection{Persamaan Regresi Berganda}

Penelitian tersebut diatas menggunakan 6 parameter yang terdiri atas 1 parameter (Tingkat Pertumbuhan Ekonomi) yang berfungsi sebagai dependend variable atau variabel tergantung dan 5 parameter lain (Tingkat upah minimum/UMP, Realisasi PMA, Realisasi PMDN, Angka atau Jumlah Pengangguran dan Kesempatan kerja/Bekerja) yang berfungsi sebagai independent variable atau variabel bebas, alat statistika yang digunakan dalam penyelsaian penelitian ini adalah SPSS 19 Hasil yang berupa Multiple Linear Regression adalah sebagai berikut:

Jadi dapat disimpulkan bahwa variabel Tingkat Pertumbuhan Ekonomi (PDB) di propinsi Banten pada periode 1999-2013 dipengaruhi oleh Tingkat upah minimum propinsi (UMP), Angkatan Kerja (AK), Jumlah Penganggur (JP), Perusahaan Modal Dalam Negeri (PMDN) dan Perusahaan Modal Asing (PMA), dengan persamaan regresi berganda sebagai berikut:

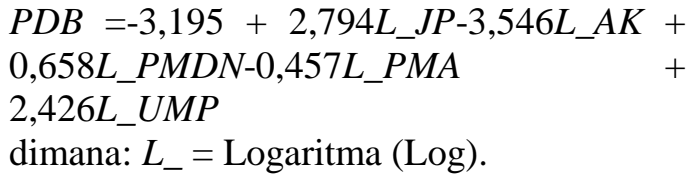

Koefisien konstanta bernilai negatif menyatakan bahwa dengan mengasumsikan ketiadaan variabel Tingkat upah minimum propinsi (UMP), Angkatan Kerja (AK), Jumlah Penganggur (JP), Perusahaan Modal Dalam Negeri (PMDN) dan Perusahaan Modal Asing (PMA), maka Tingkat Pertumbuhan Ekonomi (PDB) di propinsi Banten pada periode 1999-2013 mengalami penurunan.

Koefisien regresi Jumlah Penganggur (JP) bernilai positif dan signifikan berpengaruh, menyatakan bahwa dengan mengasumsikan ketiadaan variabel independen lainnya, maka apabila Jumlah Penganggur (JP) mengalami peningkatan, maka Tingkat Pertumbuhan Ekonomi (PDB) di propinsi Banten pada periode 1999-2013 mengalami peningkatan.

Tabel 1. Output Persamaan Regresi Berganda Pengangguran di Propinsi Banten Periode 2009-

Coefficients $^{\mathrm{a}}$ 2013.

\begin{tabular}{|c|c|c|c|c|c|}
\hline \multirow[b]{2}{*}{ Model } & \multicolumn{2}{|c|}{ Unstandardized Coefficients } & \multirow{2}{*}{$\frac{\text { Standardized Coefficients }}{\text { Beta }}$} & \multirow[b]{2}{*}{$\mathrm{t}$} & \multirow[b]{2}{*}{ Sig. } \\
\hline & $\mathrm{B}$ & Std. Error & & & \\
\hline 1 (Constant) & $-3,195$ & 22,441 & & $-0,142$ & 0,890 \\
\hline $\mathbf{J P}$ & 2,794 & 1,081 & $\mathbf{0 , 4 1 1}$ & 2,585 & $\mathbf{0 , 0 2 9}$ \\
\hline AK & $-3,546$ & 4,508 & $-0,220$ & $-0,787$ & 0,452 \\
\hline PMDN & 0,658 & 0,376 & 0,35 & 1,749 & 0,114 \\
\hline PMA & $-\mathbf{0 , 4 5 7}$ & 0,156 & $-0,247$ & $-2,935$ & $\mathbf{0 , 0 1 7}$ \\
\hline UMP & 2,426 & $\mathbf{1 , 5 2 0}$ & 0,428 & $\mathbf{1 , 5 9 6}$ & 0,145 \\
\hline
\end{tabular}

a. Dependent Variable: PDB

Sumber: Data Diolah (2015) 
Koefisien regresi Angkatan Kerja (AK) bernilai negatif, tidak signifikan dan tidak berpengaruh, menyatakan bahwa dengan mengasumsikan ketiadaan variabel independen lainnya, maka apabila Angkatan Kerja (AK) mengalami peningkatan maka Tingkat Pertumbuhan Ekonomi (PDB) di propinsi Banten pada periode 1999-2013 mengalami penurunan.

Koefisien regresi Perusahaan Modal Dalam Negeri (PMDN) bernilai positif dan signifikan berpengaruh, menyatakan bahwa dengan mengasumsikan ketiadaan variabel independen lainnya, maka apabila Perusahaan Modal Dalam Negeri (PMDN) mengalami peningkatan, maka Tingkat Pertumbuhan Ekonomi (PDB) di propinsi Banten pada periode 1999-2013 mengalami peningkatan.

Koefisien regresi Perusahaan Modal Asing (PMA) bernilai negative signifikan berpengaruh, menyatakan bahwa dengan mengasumsikan ketiadaan variabel independen lainnya, maka apabila Perusahaan Modal Asing (PMA) mengalami peningkatan maka Tingkat Pertumbuhan Ekonomi (PDB) di propinsi Banten pada periode 1999-2013 mengalami penurunan.

Koefisien regresi Tingkat upah minimum propinsi (UMP), bernilai positif dan signifikan berpengaruh, menyatakan bahwa dengan mengasumsikan ketiadan variabel independen lainnya, maka apabila Tingkat upah minimum propinsi (UMP) mengalami peningkatan, maka Tingkat Pertumbuhan Ekonomi (PDB) di propinsi Banten pada periode 1999-2013 mengalami peningkatan.

\subsection{Uji Multikolinieritas}

Uji Multikolinieritas bertujuan untuk menguji apakah dalam model regresi ditemukan adanya korelasi yang tinggi atau sempurna antar variabel independen. Jika antar variabel independen terjadi Multikolinieritas sempurna, maka koefisien regresi variabel independen tidak dapat ditentukan dan nilai standard error menjadi tak terhingga. Jika Multikolinieritas antar variabel independen tinggi, maka koefisien regresi variabel independen dapat ditentukan tetapi memiliki nilai standard error tinggi berarti nilai koefisien regresi tidak dapat diestimasi dengan tepat.

1. Terlihat dari Tabel 4, hasil pengolahan SPSS 19 nilai $R^{2}$ cukup tinggi sebesar 93,9\%, sedangkan kebanyakan variabel independen memiliki nilai $t$ statistik yang signifikan pada $\alpha=5 \%$ dan $20 \%$. Oleh karena itu $R^{2}$ yang tinggi dan kebanyakan variabel independennya signifikan, maka tidak ada indikasi terjadi multikolonearitas antar variabel independen.

2. Berdasar Tabel 2 yaitu tampilan matriks korelasi pair-wise correlation antar variabel independen semuanya dibawah 0,80 , kecuali antara variabel Tingkat upah minimum propinsi (UMP) dengan Angkatan Kerja (AK) yang korelasinya sedikit diatas 0,80 . Jadi dapat disimpulkan bahwa terdapat multikolinearitas ringan antara variabel UMP dengan AK.

3. Nilai $R^{2}$ keseluruhan model cukup tinggi, sebesar 93,9\% (Tabel5), sedangkan nilai parsial korelasi berkisar masing-masing untuk JP, AK, PMDN, PMA dan UMP adalah 0,$653 ;-0,254 ; 0,504 ; 0,699$ dan 0,470 . Oleh karena nilai parsial juga tinggi, maka tidak ada indikasi multikolinearitas, untuk lebih jelasnya lihat Tabel 3.

4. Berpedoman pada Tabel 4, terlihat JP, PMDN dan PMA mempunyai nilai Tolerance 0,268; 0,164 dan 0,957 (diatas $0,10)$ dan VIF 3,736; 6,113 dan 1,045 (dibawah 10) sedang untuk AK dan UMP Tolerance 0,087 dan 0,097 (dibawah $0,10)$ dan VIF 11,531 dan 10,609. Untuk parameter JP, PMDN dan PMA tidak ada multikolinearitas sedang untuk parameter AK dan UMP ada multikolinearitas ringan. 
Coefficient Correlations ${ }^{\mathrm{a}}$

Tabel 2. Koefisien Korelasi Antar Variabel

\begin{tabular}{|c|c|c|c|c|c|c|c|}
\hline \multicolumn{3}{|c|}{ Model } & UMP & PMA & $\mathrm{JP}$ & PMDN & $\mathrm{AK}$ \\
\hline \multirow[t]{10}{*}{1} & Correlations & UMP & 1,000 &,- 084 &,- 161 & ,031 &,- 881 \\
\hline & & PMA &,- 084 & 1,000 & 094 & ,020 & ,068 \\
\hline & & $\mathrm{JP}$ &,- 161 & ,094 & 1,000 &,- 771 & ,270 \\
\hline & & $\begin{array}{l}\text { PMD } \\
\mathrm{N}\end{array}$ & ,031 & ,020 &,- 771 & 1,000 &,- 346 \\
\hline & & $\mathrm{AK}$ &,- 881 & ,068 & ,270 &,- 346 & 1,000 \\
\hline & Covariances & UMP & 2,312 &,- 020 &,- 264 & ,018 & $-6,040$ \\
\hline & & PMA &,- 020 & ,024 & 016 & ,001 & , 048 \\
\hline & & JP &,- 264 & ,016 & 1,168 &,- 313 & 1,314 \\
\hline & & $\begin{array}{l}\text { PMD } \\
\mathrm{N}\end{array}$ & ,018 & 001 &,- 313 & ,142 &,- 586 \\
\hline & & $\mathrm{AK}$ & $-6,040$ & ,048 & 1,314 &,- 586 & 20,321 \\
\hline
\end{tabular}

Sumber : Data Diolah (2015)

Tabel 3. Parsial Korelasi

\begin{tabular}{|l|l|r|}
\hline No. & \multicolumn{1}{|c|}{ Variable } & \multicolumn{1}{|c|}{ Partial Correlations } \\
\hline 1 & JP & 0,653 \\
\hline 2 & AK & $-0,254$ \\
\hline 3 & PMDN & 0,504 \\
\hline 4 & PMA & 0,699 \\
\hline 5 & UMP & 0,470 \\
\hline
\end{tabular}

Sumber: Data Diolah (2015)

Tabel 4. Tolerance dan VIF Independen Variabel

\begin{tabular}{|l|l|r|r|}
\hline \multicolumn{1}{|c|}{ No. } & \multicolumn{1}{|c|}{ Variabel } & Tolerance & \multicolumn{1}{|c|}{ VIF } \\
\hline 1 & JP & 0,268 & 3,736 \\
\hline 2 & AK & 0,087 & 11,531 \\
\hline 3 & PMDN & 0,164 & 6,113 \\
\hline 4 & PMA & 0,957 & 1,045 \\
\hline 5 & UMP & 0,097 & 10,609 \\
\hline
\end{tabular}

Sumber: Data Diolah (2015)

\subsection{Uji Autokorelasi}

Uji autokorelasi bertujuan menguji apakah dalam suatu model regresi linear terdapat korelasi antar kesalahan pengganggu (residual) pada periode $t$ dengan kesalahan pada periode $t-1$ (sebelumnya). Jika terjadi korelasi, maka dinamakan terdapat permasalahan autokorelasi. Autokorelasi muncul karena observasi yang berurutan sepanjang waktu berkaitan satu sama lain (Janie, 2012).

Masalah ini timbul karena residual tidak bebas dari satu pengamatan ke pengamatan yang lain. Hal ini sering ditemukan pada data runut waktu (time series) karena gangguan pada seseorang/individu/kelompok cenderung mempengaruhi gangguan pada individu/kelompok yang sama pada periode berikutnya. 
Model Summary ${ }^{\mathrm{b}}$

Tabel 5. Model Uji Durbin Watson (Uji Autokorelasi)

\begin{tabular}{|l|c|r|r|l|l|}
\hline Model & R & R Square & Adjusted R Square & Std. Error of the Estimate & Durbin-Watson \\
\hline 1 &, $969^{\mathrm{a}}$ &, 939 &, 905 &, 40329 & 1,755 \\
\hline
\end{tabular}

a. Predictors: (Constant), UMP, PMA, JP, PMDN, AK

b. Dependent Variable: PDB

Sumber: Data Diolah (2015)

Tabel. 6. Tabel Uji Durbin Watson untuk Penentuan Ada Tidak Autokorelasi.

\begin{tabular}{|c|c|c|c|c|}
\hline $\begin{array}{l}\text { Tolak } \mathrm{H}_{\mathrm{o}} \text {, berarti } \\
\text { ada autokorelasi } \\
\text { positif }\end{array}$ & $\begin{array}{l}\text { Tidak dapat } \\
\text { diputuskan }\end{array}$ & $\begin{array}{l}\text { Tidak menolak } \mathrm{H}_{\mathrm{o}} \\
\text { berarti tidak ad } \\
\text { autokorelasi }\end{array}$ & $\begin{array}{l}\text { Tidak dapat } \\
\text { diputuskan }\end{array}$ & $\begin{array}{l}\text { Tolak } \mathrm{H}_{\mathrm{o}} \text {, berarti } \\
\text { ada autokorelasi } \\
\text { negatif }\end{array}$ \\
\hline & & 2 & & 4 \\
\hline
\end{tabular}

Sumber: Data diolah (2015).

Ada beberapa cara yang dapat digunakan untuk mendeteksi ada tidaknya autokorelasi. Salah satu cara yang umum digunakan untuk mendeteksi adanya autokorelasi dalam regresi linear berganda adalah dengan Uji Durbin Watson (DW). Uji D-W merupakan salah satu uji yang banyak dipakai untuk mengetahui ada tidaknya autokorelasi. Hampir semua program statistik sudah menyediakan fasilitas untuk menghitung nilai $d$ (yang menggambarkan koefisien DW). Nilai $d$ akan berada di kisaran 0 hingga 4, seperti terlihat pada Tabel 6 .

Apabila $d$ berada diantara 1,54 dan 2,46, maka tidak ada autokorelasi, dan bila nilai $d$ ada di antara 0 hingga 1,1 mengandung autokorelasi positif, dan bila nilai $d$ ada di antara 2,90 hingga 4 ada autokorelasi negatif.

Berdasar hasil uji yang ada pada Tabel 5 terhadappersamaan analisa regresi berganda pertumbuhan ekonomi di Propinsi Banten periode 1999-2013, diperoleh Nilai Durbin Watson $(\mathrm{DW})$ adalah $=1,755$. Berarti $d$ berada diantara 1,54 dan 2,46 maka kesimpulan bahwa Persamaan Analisa Regresi Berganda Pertumbuhan Ekonomi di Propinsi Banten periode 1999-2013 tidak menolak Ho; berarti tidak ada autokorelasi.

\subsection{Uji Heteroskedastisitas}

Asumsi klasik berikutnya dalam model regresi adalah Homoskedastisitas atau memiliki varian yang sama. Ada dua cara pendeteksian ada tidaknya Heteroskedastisitas, yaitu dengan metode grafik dan Uji Glejser.

\section{Uji Glejser}

Hasil dapat dilihat pada Tabel 7 dengan jelas menunjukkan variabel Tingkat upah minimum propinsi (UMP), Angkatan Kerja (AK), Jumlah Penganggur (JP), Perusahaan Modal Dalam Negeri (PMDN) dan Perusahaan Modal Asing (PMA) memiliki nilai signifikansi 0,$790 ; 0,665 ; 0,662 ; 0,859$ dan 0,095 yang kesemuanya di atas 0,01. Berarti tidak terdapat Heteroskedastisitas dalam model ini, dengan kata lain semua variabel independen yang terdapat dalam model ini memiliki sebaran varian yang sama atau homogen. 
Coefficients $^{\mathrm{a}}$

Tabel 7. Uji Heteroskedastisitas

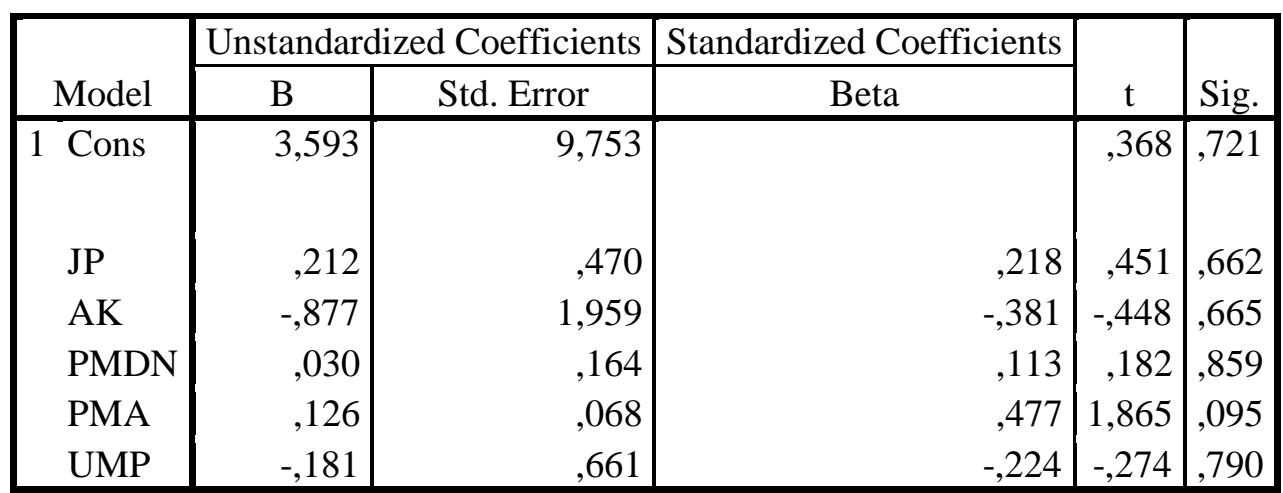

a. Dependent Variable: AbsUi

Sumber: Data diolah (2015).

\section{KESIMPULAN}

1. Tingkat upah minimum propinsi/UMP, Jumlah Penganggur (JP), Perusahaan Modal Dalam Negeri (PMDN) dan Perusahaan Modal Asing (PMA) berpengaruh secara signifikan terhadap tingkat pertumbuhanekonomi di propinsi Banten pada periode 1999-2013.

2. Tingkat upah minimum propinsi/UMP, Jumlah Penganggur (JP), Perusahaan Modal Dalam Negeri (PMDN) memberikan kontribusi positif dan signifikan, sedangakan Perusahaan Modal Asing (PMA) memberikan kontribusi negatif dan signifikan terhadap tingkat pertumbuhanekonomi di propinsi Banten pada periode 1999-2013.

\section{Saran}

Sentra industri propinsi Banten perlu diadakan peng-cluster-an atau penataan kembali mana yang termasuk industri high technology dan mana yang low technology atau sering dikatakan industri manufaktur, sehingga pemerintah propinsi mudah dalam penentuan SDM baik jumlah dan tingkat kecakapan atau skill yang dibutuhkan.

Balai Latihan Kerja (BLK) yang sekarang ada di Serang masih tidak cukup, antara pendaftar dan yang diterima timpang, sehingga perlu di bangun BLK-BLK didaerah lain (Cilegon, Pandegelang, Rangkas dan Tangerang), sehingga tenaga terampil atau skill yang dibutuhkan oleh dunia kerja dapat dipenuhi dan tentunya akan meningkatkan SDM dan mempunyai nilai jual yang kompetitif termasuk menjadi TKI yang terampil.

Pemerintah propinsi Banten jangan melupakan sektor ketahanan pangan, karena ini merupakan penyerap SDM yang besar. Bagaimana majunya sektor industri tapi bila tidak ditopang dengan sektor pertanian, maka propinsi Banten hanya bergantung pada propinsi lain dalam memenuhi kebutungan pangan penduduknya. Perlu disiapkan teknologi pertanian yang maju sehingga petani tidak alih profesi dan bertahan dengan profesinya karena tetap memberikan pendapatan yang tidak kalah bila menjadi karyawan.

Pemerintah propinsi Bantenharus mempermudah birokrasi dalam pendirian dan memberikan ijin investasi pemodalan dalam negeri (PMDN) maupun investasi pemodalan asing (PMA) dengan tujuan mengurangi praktek ekonomi biaya tinggi.

Pemerintah propinsi Banten juga harus memperbaiki infrastruktur termasuk mempermudah dalam penyediaan lahan industri baik itu PMDN maupun PMA. Lebih baik dipusatkan dalam Zona Industri, sehingga fasilitas-fasilitas industri dapat terintegrasi seperti Listrik, Air, Pengolahan Limbah dan akses Pelabuhan. 
Penelitian ini mempunyai keterbatasan, sehingga dapat dikembangkan dengan variabel-variabel lain yang lebih variatif seperti angka kemiskinan, total kumulatif investasi, tingkat pendidikan dan lain-lain terhadap faktor makroekonomi di propinsi Banten pada periode 1999-2013.

\section{DAFTAR PUSTAKA}

1. BPS., 1999 -2013, Biro Pusat Statistik Propinsi Banten, Penerbit Propinsi Banten, Serang.

2. Dewi. (2010). Analisis Tingkat Pengangguran dan Faktor-Faktor yang Mempengaruhi di Propinsi Sumatera Utara. Fakultas Ekonomi Universitas Sumatera Utara.

3. Ekasari. (2006). Analisis Tingkat Pengangguran dan Faktor-Faktor yang Mempengaruhi di Propinsi Sumatera Selatan. Fakultas Ekonomi Universitas Sriwijaya.

4. Firdaus, M. (2011). Aplikasi Ekonometrika untuk Data Panel dan Time Series, Cetakan Pertama.Bogor: IPB Press.

5. Griffiths, A., Wall, S. (2005). Applied Economics. 9-th Edition, Essex: Financial Time Prentice Hall, Pearson Education Limited.

6. Gujarati, D., Zain, S. (2006). Ekonometrika Dasar. Cetakan Keenam. Jakarta: Erlangga.

7. Juanda, B., Junaidi. (2012). Ekonometrika Deret Waktu Teori \& Aplikasi. Edisi Pertama. Bogor: IPB Press.

8. Janie, D.N.A. (2012). Statistik Deskriptif \& Regresi Linear Berganda Dengan SPSS. Cetakan Pertama. Semarang: Semarang University Press.

9. Wahyu, W.W. (2009). Analisis Ekonometrika dan Statistika dengan EViews. Edisi Kedua.Yogyakarta: UPP STIM YKPN.

10.Mankiw, N.G. (2006). Principles of Economics Pengantar Ekonomi Makro. Edisi Ketiga. Jakarta: Salemba Empat.
11.Nugrahani, T.S, Tarioko, D.H. (2012). Perbedaan Pertumbuhan Ekonomi, Investasi Domestik dan Ekspor Antara Sebelum dan Sesudah Krisis. Bank Indonesia, Jakarta.

12.Merizal. A.S. (2008). Analisis Tingkat Pertumbuhan Ekonomi dan FaktorFaktor yang Mempengaruhi di Propinsi Lampung. Fakultas Ekonomi Universitas Lampung.

13.Mustika, A.C.D. (2010). Analisis Tingkat Pengangguran dan Faktor-Faktor yang Mempengaruhi di Kota Semarang. Fakultas Ekonomi Universitas Diponegoro.

14.Rizka, F.K. (2007). Analisis Tingkat Pengangguran dan Faktor-Faktor yang Mempengaruhi di Indonesia. Fakultas Ekonomi Universitas Indonesia.

15.Soebagiyo. (2005). Analisis Tingkat Pengangguran dan Faktor-Faktor yang Mempengaruhi di Propinsi Jawa Tengah. Fakultas Ekonomi Universitas Diponegoro.

16.Sukirno, S. (2005). Ekonomi Makro. Edisi Keempat.Jakarta: Erlangga. 